\title{
Forum
}

As a regular feature of Religion and American Culture, the editors invite scholars to comment from different perspectives on an issue or problem central to the study of religion in its American context. The FORUM format is designed to foster the cross-disciplinary study of religion and American culture and to bring to the readers of the journal the latest thoughts of scholars on timely, substantial topics. Contributors to the FORUM are asked to present brief essays or "thought pieces" instead of carefully documented articles.

This FORUM is a little different from those in the past. First, we decided to run a series of essays on a single topic through two issues in 2019. Second, we asked Ari Y. Kelman and Kathryn Lofton to serve as guest curators, assembling authors from different disciplines and perspectives to engage with a remarkable text from five decades ago, but with themes that still resonate today.

\section{The Religious Situation, 1968 (Part 1)}

This FORUM uses a volume published in 1968 to reflect on the religious situation today. The Religious Situation: 1968 announced its intention to be "The First in a Series of Annual Volumes." As it turned out, only one additional volume was published, in 1969. The 1968 collection reprints famous essays (such as "Civil Religion in America" by Robert Bellah and "Religion as a Cultural System" by Clifford Geertz) and issues for the first time many more, including reports on South India and Japanese peace movements; reflections on idolatry, secularization, and secularity; and updates on Jews, Catholics, and Mormons. There is not a single female author; only one author is a person of color. Every essay speaks with enormous diagnostic confidence about its designated subject and with differing sensitivities toward the significant cultural and political tumult that have come to be associated with 1968. There is not a lot of mirth or irony.

Religion and American Culture: A Journal of Interpretation, Vol. 29, Issue 1, pp. 1-35, ISSN: 10521151, electronic ISSN: 1533-8568. (C) 2019 by The Center for the Study of Religion and American Culture. All rights reserved. Please direct all requests for permission to photocopy or reproduce article content through the University of California Press's Reprints and Permissions web page, http://www.ucpress.edu/journals.php?p=eprints. DOI: https://doi.org/10.1017/rac.2019.1. 
In other words: This is a volume very much of its time. Any historian would recognize many contextual elements that indicate its specific moment. Authors generally agree that church attendance is on the decline. Contributors see Vatican II as an inevitable liberalization of the Catholic Church. The Protestants think ecumenism is on the rise. Cold War fears about Russia and the Global South unite several essays, and Cold War glee about American exceptionalism define the tenor of optimism about religious freedom throughout. Nobody mentions the 1965 Immigration Act, and none of the authors sense the Silent Majority that will soon fuel the rise of evangelical voices in the public sphere.

So why return to this volume? Because its authors seek to describe their religious moment and diagnose what their futures might be. This exercise is something of a scholarly ritual, and one we thought it valuable to revisit, with the perspective of fifty years since the original publication. What emerged was less a reflection on "the religious situation" in 1968, and more of a collection of perspectives on how things have changed and how they have not.

We asked scholars to reflect on a specific essay, and answer two questions: Does the essay's argument stand the test of time? What do you think is the status of its subject today? We don't assume anyone has read all of the essays in The Religious Situation: 1968, so we encouraged the contributors to be inspired by, but not defined by, those original essays. We hope readers can use these essays to think about the status of certain perennial subjects in the study of American religion.

\section{The Catholic Crisis}

\section{Kathleen Holscher}

To discuss American religion in 1968 from the perches of the academy was to reckon with crisis. A sense of crisis runs through the essays that make up The Religious Situation: 1968, and crisis takes center stage in Thomas O'Dea's contribution on the Catholic Church. In his chapter, titled "The Catholic Crisis: A Second Chance for Western Christianity," the sociologist O'Dea proceeds from the premise that Christianity is engulfed in a crisis of meaning vis-à-vis the technologies, ideologies, and economic and scientific pursuits of the modern world, and he uses his essay to develop the cautious proposition that the Catholic Church is the last best hope for 
Christianity, in its varied denominational forms, to find relevance in that world while preserving its "deeper character and basic identity" (295). Catholicism, O'Dea writes, "stands as a . . . surrogate for Christianity" in this consequential enterprise (295).

O'Dea's hopefulness about the Catholic Church's ability to navigate the Christian crisis at midcentury was hitched to the aggiornamento, or updating, project of its Second Vatican Council: "The Catholic attempt at aggiornamento ... represent[s] a great and indeed probably final opportunity for Christianity" (297). Indeed, for most professional observers of the Church in the 1960s, Vatican II felt like an epochal event. During the Council, which lasted from 1962 to 1965, more than two thousand bishops from around the world, including 240 from the United States, met in Rome with the purpose of charting the Church's path forward in relation to modernity. For O'Dea, Catholicism's unique potential for finding this way forward came from its existence as "an unbroken community of faith," which in turn preserved a space for intraecclesial dialogue between reformers on one hand and guardians of tradition on the other. "Only a unified body can provide the setting for genuine dialogue among . . . various . . . perspectives," he argued (294). Although O'Dea wasn't commenting as a Catholic, his essay echoes with a triumphalism-a confidence in Catholicism's achievements-that was common among midcentury Catholic (and sometimes non-Catholic) accounts of Vatican II.

Catholic triumphalism has not aged well. We know now, with the hindsight afforded us by half a century, that church attendance and religious vocations plummeted during the late 1960s. We know that 1968 was also the year of Paul VI's encyclical Humanae Vitae, and that American Catholics largely ignored its prohibition on artificial contraception. We also know that Vatican II's legacy remains contested today, not only among bishops and theologians-the men (and they were all men) $\mathrm{O}^{\prime}$ Dea highlighted in his piece-but also among folks who remain in the pews. In 2018, the Catholic Church retains a structure that might suggest "unbroken community," but as evidenced by Archbishop Carlo Maria Viganó's recent and very public letter calling for the current pope's resignation, its so-called liberal and conservative factions hardly appear to be rising to O'Dea's call for dialogue at "the highest possible intellectual level" (294).

For the last decade and a half, the Catholic Church in the United States and globally has also faced another crisis, in the onslaught of revelations of clerical sexual violence against young people, and of cover-ups of that violence by bishops. This "new" crisis (which is really no longer new at all) arguably began in 2002, 
when the Boston Globe broke its investigation of clerical sexual abuse in the Archdiocese of Boston, and it reached its most catastrophic stage thus far this past year, with the Pennsylvania grand jury report, the removal from public ministry of Cardinal Theodore McCarrick, and similar developments. Given recent events, it would be all but impossible to read O'Dea's reflections on 1968 without making the connection between his "Catholic crisis" and the language of a "Catholic crisis" spilling out of newspapers and newsfeeds in our own moment.

So to read O'Dea's essay in 2018 is to move between two Catholic crises separated by fifty years. Doing so raises questions, not only about the historical relationship between these events, but also, and, I think, more interestingly, about the hermeneutics of religious crisis, and about how centering crises in scholarship intersects with other critical possibilities for approaching the history of Catholicism in the United States. Here I consider Vatican II as an episode in a Catholic crisis (one recognized at the time by $\mathrm{O}^{\prime}$ Dea and by many others in and out of the Church); over against episodes of clerical sexual violence, which also happened during the second half of the twentieth century, but which were not publicly recognized as components of a crisis until decades later. This juxtaposition reveals a need for movement away from a hermeneutics of crisis as we reckon with the history of clerical sexual abuse, and it suggests a different hermeneutics - a hermeneutics of silence-as one resource that might help us approach the study of sexual violence differently.

Speculation about a cause-and-effect relationship between the Catholic crisis of 1968 and the most recent Catholic crisis is easy to locate. Prominent "conservative" voices in the U.S. Church have drawn fire for suggesting that it was Catholicism's capitulation to the modern world during the late 1960s and 1970s, in the form of its embrace of the sexual revolution, and homosexual subcultures specifically, that fomented clerical sexual abuse during that period. Catholic "liberals" also participate in such speculation, but are more likely to point to the Church's failure to engage the modern world sufficiently, and to cite, for example, its slowness to respect lay forms of authority at the parish and diocesan levels, and its retention of mandatory celibacy for clergy.

I am uninterested in joining cause-and-effect speculation, but I do want to consider these crises together. Today's Catholic crisis is changing the way that both U.S. Catholics and historians of U.S. Catholicism think about the Vatican II era. The triumphalism is gone. We are acutely aware now that tens of thousands of episodes of assault-in other words, the violent acts that are the "raw material" 
of this crisis-occurred more or less concurrently with the ecclesial dialogue O'Dea celebrates in his piece. According to the 2004 John Jay College report on the nature and scope of the violence, clerical sex abuse in the U.S. Church peaked between the late 1960s and the early 1980s, during the immediate "post-conciliar" era O'Dea wrote optimistically about. Moreover, we know now that U.S. bishops played special roles not only in Vatican II and its implementation, but also in the scourge of sexual violence that accompanied it (but went unremarked) in their home dioceses. In fact, sometimes the same men celebrated for their standout work implementing conciliar reforms did especially consequential things to perpetuate that violence. Consider (to cite only the most notorious example) Cardinal Bernard Law, who developed a reputation for his work on behalf of Christian ecumenism and interreligious dialogue while a rising bishop during the 1970s, only to later become the face of the sex abuse crisis, amid revelations of his extensive work sheltering and reassigning predatory priests in the Archdiocese of Boston.

But thinking about these crises together also presents a further opportunity; it encourages reflection on the decades that separate the two temporally, and on the silences-all the forms of "not speaking it"- that successfully deferred sex abuse as a public catastrophe until the twenty-first century. Because if Vatican II was an episode in a Catholic crisis, acknowledged and navigated as such by bishops, both in Rome and back in the United States, we see now (from our vantage point amid the present crisis) that the clerical culture those bishops lived in was a collectively and strenuously maintained state of calm. The forms of silence that made and kept this calm, that ensconced these men as they committed themselves to the "dialogue" that would become the hallmark of Catholicism's response to modernity, are suddenly striking. Where do we find ourselves once we move outside a hermeneutics of crisis, to interrogate varieties of "not speaking" as integrally Catholic practices-practices that sustained violence, even as they also sustained a culture, and that existed with dialogue as remarkable attributes of twentieth-century U.S. Catholicism?

From monastic vows to the seal of confession, silence has long played different and important roles in clerical and religious Catholic life. Keeping this in mind, we might employ a hermeneutics of silence to consider anew the culture of clerical Catholicism in the United States during the Vatican II era. Fifty years later, the U.S. bishops appear both as a religious body that acted with clear-eyed purpose traveling back and forth to Rome, and as a group of men who moved through their own Catholic worlds via habits and 
techniques of nonrecognition, especially when it came to sexual violence perpetrated on young people by their brothers (or, more rarely, sisters) in the cloth. A Catholic culture celebrated for its willingness to confront difficult topics was also a Catholic culture constituted-held together-by unanswered correspondences and cut-off conversations, by acrobatic dancings around and brusque passings over. Catholics of different sorts (lay, religious, and clerical; perpetrators, victims, and bystanders) all participated in constitutive forms of nonrecognition during the twentieth century; there were many varieties of "not speaking" sexual violence, which came to be from many different places. But when bishops did it, it had devastating consequences.

If the texts produced by the Second Vatican Council (including Gaudium et Spes, or the "Pastoral Constitution on the Church in the Modern World," which O'Dea centers in his essay) are testaments to a midcentury Catholicism engaged in dialogue, the documents of the sexual abuse crisis have come to constitute a counterarchive of the era-a repository of the silences, the practices of quiescence, that were just as integral to the constitution of Catholicism in the modern world. In the 2018 Pennsylvania report, for example, the grand jury excoriates bishops for their use of "euphemisms"; it cites euphemisms as the first rule in what it calls the Church's "playbook for concealing the truth." "Make sure to use euphemisms rather than real words to describe the sexual assaults," the jury imagines Church leaders prescribing; never say "rape"; say "inappropriate contact" or "boundary issues." The grand jury's easy distinction between "euphemisms" and "real words" is probably insufficient for, and even at odds with, any project that aims to access the lived modes of nonrecognition that ensured sexual violence would remain a noncrisis for the duration of the twentieth century. But language like this still offers us a place to start.

In "Beyond Accountability: The Queer Archive of Catholic Sexual Abuse," Anthony Petro rightly foregrounds the stories that the sex abuse archive makes available. His own emphasis is on speaking. "Breaking silence," Petro writes, "becomes a key political act . . . for survivors" (166). But where might accompanying attention to silence take us? How might unpacking the silences preserved within that same archive lead us, for example, to consider anew the affective dimensions of priestly fraternity, or clerical embodiments of sexual taboo, or the disciplines of self-censorship that have driven Catholic bureaucracy and preserved institutional unity? And how might paying attention to these themes within U.S. Catholic history help us to parse those archived silences? 
Stepping away from the hermeneutics of crisis, to interrogate supporting silence, is also a step toward a historical methodology that attends not only to episodes of violence, but also to the structures and processes by which religious institutions and actors come to inflict violence on certain people. During the twentieth century, Catholic clerical sexual violence disproportionately affected people who-by virtue of their age and their nonordained status, but also often (and in addition) by virtue of their poverty, their race, or their colonized status-occupied layered positions of marginality both in the U.S. Church and in relation to white Catholic culture. As Robert Orsi suggests in his work on children, precarious positioning was often produced-made real-via Catholic forms of theology and devotionalism, as much as by the muscle of ecclesial authority. With this in mind, we might ask: What assessments about personhood (theological, political, or otherwise) underlay those instances of Catholic violence that remained silences, unspoken by perpetrators and by their superiors? How do figures of the twentieth-century clerical imagination, like the "promiscuous" Indian girl, for example, or other varieties of "delinquent" youth (many of whom populate the archive of Catholic sexual abuse), help us to analyze the forms of power vested in these silences?

The power in and of these silences is more striking still amid the urgency of the U.S. bishops' mission in Rome during the 1960s, to engage the modern moment in a way that honored above all the dignity of the human person. "In this difficult, distraught, but developing world," O'Dea tells us, the Council identified itself "with the human aspiration to establish a political, social, and economic order which will ... help individuals as well as groups to affirm and develop the dignity proper to them" (313). Here the silences around sexual violence create a space to ask questions about this Catholic model of human dignity, as its historical life has happened via theological tomes, papal encyclicals, and conciliar constitutions. Amid the bishops' urgent discussions of dignity, what human problems went un-engaged? Whose human pain remained unremarked? And how did the Council's talk of dignity translate, or fail to translate, not only in public venues, but also in intimate, day-to-day relationships that compose mission, parish, and diocesan life in the United States and around the world?

Finally, the relationship between silence and marginality presses us to think differently about the Catholic crisis of our own time- to ask questions about its contours, to consider whether some forms of violence remain under-recognized amid its urgent exchanges. For example, the current casting of the Catholic sexual 
abuse crisis in the United States-particularly by the national mediais delineated by East Coast geography, and populated by white Catholic perpetrators and victims. In this way, its widespread reporting has had the effect of obscuring extraordinary rates of clerical sexual violence within Indigenous, Black, and Latinx communities, and in lands colonized over the last century and a half by the United States. Where I live in New Mexico, the per capita rate of clerical sex abuse during the twentieth century was astronomical - substantially higher even than in the dioceses detailed in the Pennsylvania report. And yet the faces of the current "Catholic crisis" are not those of New Mexican priests or of Nuevomexicano children. In our own time, albeit in different ways, silences continue to accompany Catholic crises, as they do public crises of many sorts, and those silences will continue to require our attention. It is only through this attention that we can develop adequate accounts of the "religious situation" of 1968, or of 2018, or of any moment in U.S. religious history.

Kathleen Holscher is Associate Professor of Religious Studies and American Studies and holds the endowed chair of Roman Catholic Studies at the University of New Mexico.

\section{Civil Religion in America}

\section{Jonathan Ebel}

I am writing this piece two weeks before the 2018 midterm elections, in which I had hoped to be a candidate to represent Illinois's thirteenth congressional district in the House of Representatives. The fact that I filed candidacy papers with the Federal Election Commission, gathered the signatures necessary to appear on the ballot in Illinois; raised enough money to run a serious campaign; and devoted countless hours to traveling, meeting, greeting, canvassing, organizing, marching, dialing, and asking family, friends, and volunteers to do the same should not be seen as an entirely rational choice. I did what I did because of what I felt and because those feelings would not let me go. I first felt them on November 9, 2016. From that day on, those feelings followed me around, distracted me in nearly every situation, and ultimately convinced me that I would not be able to live with myself if I didn't try to bring to Congress some of the integrity, compassion, and 
intellectual curiosity that define my district. To react to those feelings was to turn my life and the life of my family upside down. It was also to acknowledge the real power of civil religious affect in twenty-first century America.

To the question of whether Robert Bellah's arguments in "Civil Religion in America" remain valid in 2018, my response is a strong, if qualified, yes. To my eye he makes four arguments in his essay. The first is that there is, in America, "an elaborate and well institutionalized civil religion ... [that] has its own seriousness and integrity and requires the same care in understanding that any other religion does." His second argument is that "there are . . . certain common elements of religious orientation that the great majority of Americans share," and that our civil religion is the stuff of this consensus. A third argument, connected to the trials of Vietnam, then thickening the air Bellah was breathing, is that if America weathered the crisis of the Vietnam War and did not succumb to its basest temptations the result could be "a major new set of symbolic forms," perhaps "a new civil religion of the world," which "could be accepted as a fulfillment and not a denial of American civil religion." His fourth argument, slipped in under the wire but suffusing the entire essay, is for the ongoing normative relevance of American civil religion. Bellah's final sentence reads, "But it is a heritage of moral and religious experience from which we still have much to learn as we formulate the decisions that lie ahead."

"Civil Religion in America," although not Bellah's last word on the topic of civil religion, has held up well over five decades. His arguments for the existence of civil religion, for its ability to connect and reflect connection, and for its ability to impart moral lessons and shape understandings of ethical action seem quite solid-that is, as long as we agree that "common elements of religious orientation" and a shared "heritage of moral and religious experience" don't equate to identical conclusions about how America ought to act in the world and what Americans owe and are owed by their nation. From Broadway's Hamilton: An American Musical to the churning streets of Charlottesville, Virginia, Americans' relationships to the trials of the Revolution, the Civil War, and Vietnam differ among themselves today and surely diverge from the relationships of Americans fifty years ago to those same trials. But if we were to compare the reactions of Democratic supporters of Barack Obama and Republican supporters of Donald Trump to the inaugural addresses of 2008 and 2016 respectively, my sense is that the substrate logics would be very similar. One candidate's words would be described as representing a near perfect expression of what America means and what God 
intended this nation to be. The other's words would be described as misguided at best, heretical at worst, and the speaker seen as an affront to the true America. I do not doubt that voices on both sides would frame their support or resistance in language, ideas, and symbols drawn from the repository of American civil religion. The anti-Obama Tea Party and anti-Trump Indivisible are but two examples. There is a powerful set of ambiguities in American civil religion. Bellah did not describe them fully, but he developed a language and a framework to help analyze them.

This brings me to the second question: What is the status of civil religion in America in 2018? The most pertinent consideration here seems to be whether differences over how to live American civil religion elicit responses so divergent, so contentiously opposite, that we now despair of something like a lived consensus. Ethicist John Carlson argued in his September 2017 essay "Losing Our Civil Religion" that the unceasing divisiveness of Donald J. Trump is pushing us in that direction. He writes, "[A]s the face of the Republican Party, President Trump now represents the greatest threat to American civil religion. Unlike the left, the new right is cynical, calling forth the darker angels of our nature." I agree with Carlson that we are in the midst of what Bellah might call a fourth time of trial - and how ironic, given Bellah's attention to presidential inaugurals, that a president would be the cause this trial. This state of crisis is the status of my subject in 2018, a year in which otherwise sober-minded academics do crazy civil religious things like run for Congress, fundraise for other candidates, and march in parades that aren't related to commencement. Formerly staid folk from all corners of the country are doing these things because they believe it may all be falling apart. And by "it" they mean America as a nation aspiring to righteousness, sensitive to the moral burdens we bear as beneficiaries of a remarkable set of blessings, a place where laws and truth and loyalty and service and fidelity and compassion matter, not simply as window dressing or as road kill en route to greater wealth and power.

So this is what a civil religious trial feels like. It is different from electoral defeat, from outrage at a use or misuse of military force, or the shock of a housing market collapse. It's even different than four crashing planes, two falling towers, and three thousand dead Americans. It's not knowing if the nation will come out of the darkness. It's wondering-not hyperbolically-if democracy will die on our watch. It's caring deeply that the nation will shine forth again and feeling heartbreak with every dimming of the light. And so the things that Bellah wrote about fifty years ago come around to hit us in the gut. The pain and bewilderment that one feels-that I 
feel-when watching the latest rally or hearing the latest interview with our current president? That's civil religion doing its work. Those are emotions derived from a long-developing, ever-evolving, and often deliberately catechized sense of what this republic is morally, what it stands for today, and what we ought to be doing to make these morals and those truths active in this moment.

This crisis could be no deeper than an impossibly shallow man. But I would not count on it. Professor Susan Schreiner of the University of Chicago, a historian of early modern Christianity, has argued that the Protestant Reformation was the result (and the proliferator) of a persistent and pervasive concern about certainty. This time of trial feels analogous. A perfect storm born at the confluence of new technologies, dramatic social and economic changes, widespread feelings of disempowerment, conspiratorial thought, and amoral demagogues may already have changed our epistemological and political landscape forever. The certainties bequeathed us by centuries of scientific striving, a developing sense of human inter-connectedness, the growth of the bureaucratic state, and international alliances built for economic and geopolitical stability, may well have been bargained away for a square mile of prime real estate in downtown Moscow and a quarter-baked theory about the malign intentions of a "deep state." Whether and how to rebuild what has been torn down are the questions we will face as we assimilate the lessons of this moment.

In the rebuilding, we would do well to consider the consensus that Bellah described in the 1960s and the injustices covered over by it. John Carlson writes, "Viewed appropriately, civil religion . . . presumes a preferential option for the marginalized: a path for people of all colors, creeds, and backgrounds to join and expand the American consensus. The urgent challenge today is whether civil religion can absorb the populist forces left behind by globalization." Agreed. I would add that we have at least two other urgent challenges. The first is to combat the civil religious heresy that "American" is an ethnicity, a genetic inheritance, an identity gained only by birth. The second is to address the structures of privilege and oppression that authorize police shootings of unarmed black men, the unmaking of migrant families seeking asylum, and sexual violence perpetrated against women and children and proleptically forgiven by (white) men. A consensus that still makes room for and often encourages these injustices is a consensus that is, to say the least, in dire need of reform.

I want to close by offering a provisional response to this journal's perennial question, which has to do with the relationship of religion to other aspects of culture, and what my answers to 
questions one and two illuminate of it. Civil religion in America-the thing, not the essay - has grown in force and malignancy. Or, rather, its practitioners have grown more comfortable being forceful and malignant. But this isn't really a transformation as much as it is a mode of civil religion that has long been present. It is "the evening redness in the west" described so vividly and horrifically by Cormack McCarthy. It is the Blood Meridian that we often miss because we want McCarthy's "Kid" to get clean, to live, to escape the Judge and find some redemption. We miss it because civil religious doctrine has encouraged us to believe, with Alexander Hamilton and Aaron Burr in Lin-Manuel Miranda's duet "Dear Theodosia," that the most meaningful blowing away that happens on American soil involves children impressing their doting, patriotic parents, and that parents and kids and future generations will endure and progress if they do not throw away their shot.

Of course, Bellah's own words may also have perpetuated this blindness. I would like to return to paragraph one of his essay, to his first argument, his argument that civil religion in America is. Here he also leaves clues as to what he believes religion is. "[T]here actually exists alongside of and rather clearly distinguished from the churches an elaborate and well-institutionalized civil religion ... [that] has its own seriousness and integrity." I doubt that Bellah meant this as an exhaustive list of criteria for "religion," but it is telling that he peppers his argument with words like elaborate, seriousness, and integrity, and that he tells readers that this well-institutionalized civil religion exists alongside, but "rather clearly" differentiated from the churches. He seems to be writing to a quaintly decorous world, a world in which people could be stung by charges of heresy. He is at least writing for an audience that wants its heavenly religion and its civil religion to be unmixed, an audience that prefers that both be religions of the head-clear, intellectual, and unsullied by the passions of the heart and of the body.

Bellah believed that scholarly attention would bear out this comforting categorization. If the past handful of years have taught us anything, it is that, for better and for worse, American civil religion functions below the neck line, too, and that it taps emotions, generates feelings, and moves bodies regardless of where one stands on twenty-first-century America's political spectrum.

Jonathan Ebel is a Professor in the Department of Religion at the University of Illinois at Urbana-Champaign. 


\section{The Mormons}

\section{Jana Riess}

For every reformation there is a counter-reformation, and history does not often look on those kindly. In contrast to reformations, which bring lasting change, counter-reformations tend to be the last gasps of institutions threatened to their core by the revolutions occurring around them. Counter-reformations are about preserving and redefining the status quo, not welcoming a new world order. They are, as sociologist David L. Brewer observes in his piece on Mormonism in 1968, the desperate ghost dances of societies that fear their own impending obsolescence. As America engaged in tumultuous political and social change in the 1960s, liberalizing its stances on race, gender, and sexuality, some groups responded to the reformation happening around them by defining themselves in contrast to it, energetically hardening their opposition.

Although he never uses the term counter-reformation, that is the lens through which Brewer views Mormonism in 1968. He presents the Church of Jesus Christ of Latter-day Saints as an "anti-modern" institution that has, he says, come "so completely to terms with American middle-class mores that it is frozen there." After an early history of economic communitarianism, the church had by the 1960s allied itself with capitalism and a rugged individualist spirit; it had also become entrenched in its racist policy of denying priesthood ordination and temple entrance to anyone of African descent.

Brewer correctly identifies the latter issue as the defining antimodern characteristic of 1968 Mormonism, "blatantly out of tune with America's emerging social conscience." What's more, he correctly predicts what did, in fact, happen: that what was then called the "Negro policy" was "unlikely to change in the near future." (It would not be reversed for another ten years, in June of 1978, after the furor of the Civil Rights movement had died down. As Mormonism expanded internationally, its leaders discovered that the racial policy was an impediment to the religion's numeric growth. When a religion is in the vanguard of a counter-reformation, it hunkers down by expanding its missionary program, Ignatian-style.)

How do Brewer's other claims about Mormonism bear up fifty years later? Overall, surprisingly well. Here I highlight three areas in which Brewer's assessment proved prescient-and two others where history shows him to have missed the mark. 
First, Brewer foresees the problems inherent in Mormonism's gerontocratic leadership structure, in which only the most senior male leaders come to rule-often in their seventies, eighties, or even nineties, as was the case in early 2018, when ninety-three-year-old Russell M. Nelson took the reins. As of this writing he is ninety-four, and his two counselors in the First Presidency are eight-six and eighty-five, respectively. Brewer recognizes the challenge any religion would have in responding to change when its top leaders came of age a lifetime ago, in a different era entirely.

In fact, since Brewer wrote this essay in 1968, the age divide between Mormonism's leaders and its adherents has widened still further. In the Quorum of the Twelve Apostles-the body from which the most senior member will become the prophet and president of the Church-it has become the norm for men not to be called until they are generally in their sixties. Their children are grown; they have slowly risen through the ranks of LDS leadership; they bring with them decades of experience running different programs and committees of the Church. This is a different situation than the one that pertained in 1968. For example, when Thomas S. Monson joined the Quorum in 1963, he was just thirty-six. In other words, in 1968, the gerontocracy problem was mitigated by the presence of a few much younger men in the highest ranks of leadership; even though the Church's president in 1968, David $\mathrm{O}$. McKay, was in his nineties, the quorum also contained a few men two or even three generations younger. That is no longer the case, meaning that the gerontocracy problem Brewer identified in his assessment of Mormonism has worsened. Today's First Presidency, with its average age of 88.5, is the oldest in nearly two centuries of LDS history. Meanwhile, according to 2014 Pew data, only 16 percent of Mormon adults in the U.S. are older than sixty-five.

Brewer's assessment is also spot-on in his identification of U.S. Mormons' increasing political conservatism as a trend to watch. Citing a Mormon distrust of the federal government that began more than a century earlier, but was compounded by the polygamy crisis of the late nineteenth century, Brewer briefly discusses Mormons' dread of big government. He quotes then-apostle Ezra Taft Benson, who warned in 1965 about the dangers of Communism and the "civil rights agitation" taking place in Mississippi at that time. Benson's own allegiance with the Republican Party was well known; he had in the 1950s served as the Secretary of Agriculture in Dwight D. Eisenhower's administration, and repeatedly sounded the drum of conservative politics as the only righteous option for Latter-day Saints. 
Brewer's claim that Mormonism was becoming politically conservative obviously struck a nerve with the essay's sole respondent, University of Utah sociologist Lowell Bennion, who claims that Brewer unfairly views the whole of Mormonism through the lens of his own "particular emphases." Bennion's critique bears quoting:

The reader who is not a Mormon might well come away from Brewer's essay thinking that all Mormons are literalists, separatists, agrarian individualists, [and] arch conservatists, that the general authorities are all of one mind, and that intellectuals play no role in the Church whatever. The Mormons are not single minded. A study of the voting patterns of Utah since 1932, for instance, will show that, with one or two exceptions, Utah has followed national trends regardless of the conservative influence of some church leaders.

Bennion was correct that Utah's voting patterns largely mirrored the nation's in the first half of the twentieth century. However, Brewer was prophetic in expecting that this would not be the case much longer, and that the "arch conservatist" strain would eclipse all others. Indeed, it was already happening. In 1968, Mormons had the pride of seeing one of their own native sons run for the presidencyMichigan's Republican governor, George Romney. Although Romney did not win the GOP primary and advance to the general election, Mormons' allegiance to the GOP became a hallmark of their public image. After voting for the occasional Democrat (including Lyndon Johnson in 1964), Utah went thoroughly Republican in 1968, and it has never looked back. With the exception of Donald Trump in 2016, GOP candidates have won easy majorities, in some cases garnering three-quarters of the vote. (Trump did not crack the 50 percent barrier, but still won the state.) In retrospect, Lowell Bennion's optimism that Mormon-majority Utah would continue to follow national political trends regardless of the political views expressed by LDS leaders seems naïve.

Third, Brewer puts his finger on a major development within Mormon theology and culture that began happening after World War II: the rise of the nuclear family. "The Mormon family has become central in the defense of individualism and traditional moral values," Brewer writes. "It is to the family, more and more, that the church directs its attention, in the attempt to keep its young people 'unspotted from the world.'" Although family had always been a concern in Mormonism, the Mormon definition of family had once 
diverged sharply from the nation's; the Latter-day Saints' unusual practice of polygamy drove a wedge between them and the government of the United States. By World War II, polygamy had been disavowed by Mormon leaders for more than half a century, and a new configuration of the family became paramount: a middle-class ideal with a working father, stay-at-home mother, and a large number of children. Social science research into General Conference topics through the decades reveals that the family was discussed only about five hundred times in the entire decade of the 1930s; in the first half of this decade, by contrast (2010-2015), it was mentioned more than three thousand times. The decade of the 1960s saw the institutionalization of this new emphasis; in 1965, for example, the Church introduced its first manual for the new tradition of "Family Home Evening," when Mormon families dedicated one evening a week to learning their religion at home together. In 1970, Monday night was designated as the official and Church-approved evening for families to do this. Also in the late 1960s and early 1970s, the Church pioneered the concept of the "family to family" Book of Mormon evangelism program and the "Family: Isn't It About . . . Time?" media campaign, presenting the nuclear family as its calling card to the world.

Brewer's language goes deeper, however. He's not just arguing that the concept of the nuclear family became central to Mormonism, but that it did so specifically in the "defense" of individualism and "traditional moral values." This has proven exactly right. As the nation has become more accepting of, for example, LGBT rights and same-sex marriage, Mormon leaders have often taken a hardline stance. In the 1970s through the beginning of the twenty-first century, they condemned homosexuality as a sinful choice and homosexuals as depraved. As apostle Boyd K. Packer preached in 1978, homosexuality "is not desirable; it is unnatural; it is abnormal; it is an affliction." He also taught that anyone who believed it was an inborn trait was preaching "false doctrine." Throughout the 1970s, LDS censure of homosexuality increased in its public discourse and its internal discipline of members; in 1976, the Church Handbook made it an excommunicable offense merely to be gay, even if one was living a celibate life. It has since changed this position, and also cautiously allowed for the idea that homosexual orientation is not a moral failing but an innate or genetic predisposition. In 2018, for example, the FAQ page of the church's official website for LGBT members noted that "the intensity of same-sex attraction is not a measure of your faithfulness. Many people pray for years and do all they can to be obedient in an effort to reduce same-sex attraction, yet 
find they are still attracted to the same sex." Gone is the old advice to "pray the gay away."

Yet, church leaders have not budged an inch on same-sex marriage. Marriage between a man and a woman has become a standard-bearing issue for Mormon leaders in the defensive manner predicted by Brewer fifty years ago. In 2018, in fact, President Dallin H. Oaks of the First Presidency reiterated the church's opposition to same-sex marriage, stating that "our knowledge of God's revealed plan of salvation requires us to oppose current social and legal pressures to retreat from traditional marriage." On the official church website quoted previously, the softened tone about same-sex attraction is followed directly by a statement about the institution's ongoing opposition to same-sex marriage. The FAQ asks, "Will the church ever change its doctrine and sanction same-sex marriage?" In a word: No. The church continues to cling to a very specific definition of the nuclear family.

In these three areas-the challenges of gerontocracy, the turn toward conservative politics, and the fixation on a particular definition of the family-Brewer's essay points the way toward understanding major themes of Mormonism fifty years later. On the other hand, his analysis is hampered by two shortcomings. The first is his tendency to paint everything about 1968 Mormonism as antimodern. $\mathrm{He}$ chronicles the rise of "Correlation," the massive internal move to centralize and bureaucratize the LDS Church in the 1960s, but fails to recognize the ways in which Correlation was a thoroughly modern project. Mormonism in 1968 was becoming a religion overseen by professional businessmen, and it showed: Throughout the 1960s and 1970s the Church endeavored to run itself like a corporation, with all programs and curriculum "correlated" by a central authority and a focus on measurable growth. It was antimodern in its rejection of doctrinal innovation, but thoroughly modern in its embrace of cutting-edge marketing, international expansion, and worldly progress. Such efforts were successful in ensuring the quantifiable growth the LDS Church had come to value; the religion grew by an average of $5.7 \%$ a year in the 1960 s. It took the religion 117 years to reach its first million members, in 1947, but it exploded thereafter. By 1967, it had grown to 2.61 million members. In this sense, Mormonism was certainly not mid-ghost dance, as Brewer oversimplifies it to be. It instead was finding a willing audience of people eager for its unusual combination of antimodern theological certainty with programs and methods that were positively avant-garde. 
Second, Brewer is entirely missing any attention to women or gender. A cursory glance through the table of contents of The Religious Situation: 1968 makes it clear that this deficit was hardly unique to the chapter on Mormonism; of the more than four dozen contributors and respondents to the volume, not a single one was female, and the topic of gender was not a concern. The oversight is also entirely par for the course in much of the scholarship about Mormonism up to that time; for Thomas O'Dea's groundbreaking (and, in 1968, still definitive) sociological study, The Mormons, he did not interview a single woman.

Brewer's neglect of women, although typical of the 1960s (and still typical of the LDS leaders who came of age in that era and are now occupying the highest positions of leadership in the Church), is unfortunate in that he missed what would become a tremendously important theme that could only have strengthened his own thesis about the Church's present and future difficulties in American culture. In the 1970s, not long after Brewer's essay was published, the women's movement and specifically the Equal Rights Amendment emerged as major challenges to Mormonism's postwar emphasis on traditional roles for women. In the late 1970s, the LDS Church began publishing strongly worded pieces that opposed the Equal Rights Amendment and women working outside the home. The ERA, which had enjoyed two-thirds majority support among Mormons in Utah in 1975, was soundly defeated in the Utah legislature after the LDS Church announced its opposition. In stridently opposing the ERA - even to the point of excommunicating a Mormon feminist, Sonia Johnson, in 1979-the Church publicly retrenched its position on women's roles. The issue has not died, however, with some twenty-first century members continuing to question why women are excluded from almost all decision making in the now-sixteen-million-member denomination.

In the end, Brewer's main point is prescient: The LDS Church's commitment to a very particular configuration of society and of white, middle-class values would eventually become a stumbling block of its own making. Even as it rescinded its racist policy in 1978, it was doubling down on its objections to women's rights and gay rights. My own research, based on a national survey and discussed in the book The Next Mormons, explores these and other issues to ask how Millennials, the youngest generation of Latter-day Saint adults, are responding to issues like gender, sexuality, and race in the Church. In many ways, they are not their parents and grandparents. Although Mormon Millennials are more theologically conservative than their peers outside the Church, they are sometimes markedly more progressive than their elders within it. What's more, approximately 
half of them appear to be leaving, which is a considerable drop from the retention rate of just two generations ago, when three-quarters of them stayed.

The question now is what the Church will do, what kind of ghost dance it will fashion in response to the crisis. So far, its tools of counter-reformation have centered on a particular vision of the patriarchal nuclear family that was an American cultural icon when Mormon leaders were themselves young adults. What happens, though, when such a response not only fails to resolve the problem of disaffected young people, but actually exacerbates it, alienating them still further?

Jana Riess is a senior columnist at Religion News Service and the author of The Next Mormons.

\section{The New Relativism in American Theology}

\section{Joseph L. Tucker Edmonds}

The Crisis of Theology

"We must acknowledge that our inherited theological language has been placed in question, and it is precisely when we speak most easily in terms of that language that we speak most falsely and perversely." Robert Novak begins his essay on "The New Relativism in American Theology" with a damning and incisive critique of theology, its history, and its role and influence in the public sphere. For Novak, theology or confessional theology was inadequate to respond to the tasks and questions of the current moment. Theology, however, had the ability to break out and transform the public and the university simultaneously. In 1968, the new relativism was a mechanism to tear theology, and specifically systematic theology, from the grips of an insider, hierarchy-mediated language that could not be applied to the questions and concerns of that time. It was not the end of theology, but Novak was proposing and outlining the beginning of something new and potent within the theological enterprise. He argued that "[r]eligion like everything else has been plunged into a crisis of credibility," and it was this new relativism that augured a space and place for an auspicious and critical intervention for the resurgence of theology as a public language or tool. He suggests that, in the middle of the twentieth 
century, alongside the emergence of new subject positions and social concerns within these groups, there was an end of shared meaning and way of life, the collapse of folk religion, and the end of academic theology so tightly tethered to the "fruitful tension of Bultmann and Barth." This fruitful tension had elevated theology as a pejorative and necessary conversation partner for the maintenance of empire. This was a moment of dismantling and reconfiguring the hegemonic categories and the disciplinary methods of theology, the university, and, more specifically, the reach and influence of western Christianity. Theology as a colonial enterprise had been breached, and the emergence of new fields and methods of study were clearly emerging.

\section{Black Power and the New Relativism}

As a reader of 1968, I argue that Novak and his main thesis around the reorganization of the public, the new shape of the modern project, and the inability of certain disciplines to address these issues were right on track. He was correct to note the creative and disruptive possibilities of the moment in which he found himself and the ways that the reshaping of knowledge projects would affect not just that particular project, but society more broadly. In many ways, he is prescient when he argues that the "prospect offered to theology today is so vast that no one yet has been able to glimpse the entire range of possibilities." He is correct that this unfolding is so vast that we are still, in 2018, unfolding and responding to its disruptions in theology and the public sphere. His appraisal of its far-reaching consequences, however, are somewhat undermined by his focus. Although Novak focuses on the death of God theologies and the emergence of radical theologians and their critique of the theological discipline, he does not give nearly enough time to one of the most compelling questions of 1968-blackness and black power. James Hal Cone's publication of Black Power and Black Theology in 1969 disrupted Barth, Niehbur, Tillich, and even the black church to present a model of discourse that could respond to the twin crises of race and empire in the middle of the twentieth century. Cone's stunning intervention is notable for the ways that he both grasps for something new while not fully being willing to let go of the systems that organized the theological method and project. Cone, therefore, is most notable for the works and the schools of theological thought that follow in his wake. This new relativism, although possibly destabilizing some forms of whiteness, Christianity, and European 
models of systematic theology, does not and cannot by itself destabilize the colonial and recalcitrant categories of white supremacy.

\section{Whiteness and Contextual Theologies as the New Folk}

Therefore, for the remainder of this essay, I focus on two movements that emerged as a result of the new relativism. Whereas Novak argues that this new relativism augurs a cosmopolitan turn to the broader public and the ethical concerns of the day, I suggest that, following 1968, we see the return to "the folk" in multiple and diverse ways. Novak envisions the folk as a dying breed, or the detritus of insufficiently realized modern age, and he argues that folk religion is "a modality of religious life whose strength derives from family sentiment, local customs, and national inheritance; negatively, a modality whose strength does not come from the drive to raise questions." However, I argue that this pejorative misread of the folk or their folk religions leads to a misrecognition of their importance in the public sphere then and during the remainder of the twentieth century. The folk did not come to an end; rather, what we are introduced to is the metastasis of the folk through the lens of both whiteness and otherness. The new relativism proposed a new method for engaging multicultural and cosmopolitan identities, and it also made space for wide varieties of whiteness and their return, not as the holders or the symbol of absolute truths, but as absolutely essential to the maintenance of white supremacy. So although it is important to see the new relativism as creating the space for the rise of new disciplines like black and feminist studies and the restructuring of the theological discourse, it also makes a space for the emergence of new discourses and coalitions of whiteness. If white and European theology was no longer able or willing to maintain the hegemony of white supremacy and the European academe, then the flowering of folk religion under the umbrella and protection of new relativism would.

If many histories of the 1960s focus on the deaths of King and Kennedy, the riots throughout urban America, and the fraught moral crisis of the Vietnam War, they must also respond to the emergence of new coalitions of white separatism in response to Brown v. Board of Education, the ascendance of white-led Christian movements (Intervarsity, Campus Crusade, and the Christian Broadcasting Network) on universities and campuses around the country, and the increased flight and isolation of white communities in newly formed suburbs around the United States. Although the new relativism robs "white folk" of their most straightforward method to erase the 
outside and the other, it also enables them to respond explicitly and without apology to their folk. The new relativism, therefore, doesn't erase folk religion; it actually bolsters it. These emboldened folk, in the case outlined here, are provided the opportunity to ask and answer questions that are of interest to them. So although Novak imagines that there will be a drive to ask more heterogeneous and rigorous questions, he fails to recognize that the new relativism opened a space for all questions. Randall Balmer argues, therefore, that the origins of the religious right or the reorganization of Novak's folk, rather than being traced to Roe v. Wade and the argument around the theological and ideological issues in the antiabortion debates, can be traced to the Green v. Kennedy case and the desire for all-white Christian private schools to maintain segregated spaces. It was in the rise of these folk religious movements and universities in the post-1968 moment that we find the fiercest protectors of segregation, antiblack racism, and the preservation of folk religion and identity. These Christian organizations were willing to lose their tax exempt status and to alienate other white interests to maintain their solidly white Christian worldview. It is, therefore, important to note that, although the new relativism seemingly opened doors for new disciplines and the emergence of contextual theologies, it also opened the possibility for new venues of white hegemony, like the burgeoning white evangelical Christian complex. Therefore, I want to uphold the idea that the new relativism enables and validates all types of discourses, as it is a discourse that is uninterested or unwilling to make what Novak calls absolutist claims.

Although the emergence of these contextual theologies and Religious Right gained force throughout the 1970s, I argue that the most compelling effect of new relativism is the reorganization of the religious folk, specifically white folk, under Ronald Reagan and the birth of the Religious Right, which used the language of "religious relativism" as a means to name themselves a protected class whose cultural critique needed to be heard and addressed within the public domain. As the Religious Right coalesced into a compelling political and economic form in the 1980s, we also see the emergence of contextual theologies as no longer tied to the concerns and constraints of systematic theology and the normative constraints of the academy. It is the development of new theories of race, gender, and the body where we see theology in general and contextual theologies in particular being loosed from the grip and language of imperial disciplinary oversight. One might argue, therefore, that both the critique of the modern university and the rejection of white 
supremacy as well as the creation of new modalities for the maintenance of white Christian nationalism emerges from this new relativism. New relativism has provided space for these distinct movements to narrate their folk context and their relationship to the modern project.

Moreover, I argue that the biggest irruptions or disruptions caused by the new relativism do not fully take hold for other racialized and marginalized subjects or groups until the late 1970s and early 1980s. I argue that, similar to the emergence and trajectory of the Religious Right, it is not Cone's Black Theology and Black Power or Phyllis Tribble's writings on patriarchy and the Bible that defines the shift. It is womanism and the privileging of black women and their experiences where we actually see the logics of new relativism not just providing openings for varieties of whiteness and maleness, but where we begin to see its transgressive possibilities as it takes advantage and moves beyond the new disciplinary spaces and methods made available by the creation of Black Studies in 1968 and Women's Studies in 1970. The influence of this new relativism is to make space for new subjects and discourses in the theological project. This is precisely when theology and study of religious subjects begins to have a compelling interest in other people, and there are enough thinkers in the field to have conversations that are not primarily a response to dominant theorists or discourses. This is most profoundly seen in Delores Williams's Sisters in the Wilderness, Katie Cannon's Katie's Canon, Charles Long's Significations, and even Robert Orsi's The Madonna of 115th Street: Faith and Community in Italian Harlem. They all point to a new relativism in not only destabilizing the absolute claims of theological projects, but challenging the absolutist or hegemonic models of theological inquiry. New relativism, therefore, is important for the ways that it not only reshapes theology and the reorganization of whiteness, but also for the emergence of inter and trans disciplinary projects that address diversity and variety of the human subject.

Finally, the new relativism then and today opened ways to move beyond the hegemony of American theology and Christian discourse. Although Novak wants and insists on Christian language and engages Christian theology as a protected category, he is aware of its discursive and political limits and limitations. Novak claims that the social sciences "have opened American theology to a new understanding of the theological task." He posits that the world is collapsing around us, and he argues that part of that collapse may even include the discipline of theology as we know it. Today, this new relativism, or should we call it old, is as disruptive of the need or 
interest in Christianity or theology at all. The long and unexpected reach of the new relativism has not only disturbed the seminary and the university, as Novak predicted, but it has challenged our accounting and engagement of the "everyday" or the folk. How does relativism make space for the unexpected, the increasingly interconnected, or the wildly undefinable tasks and projects of the modern era? I believe that the continued project of the "new relativism of 1968 " is to make space for what Fred Moten calls the "fugitive subject" and subjects of the modern project. Moten's fugitivity or "the desire for and a spirit of transgression and escape of the proper and the proposed" is at the core of today's new relativism. The compelling and confounding realization is that in 2018 we are still in need of a relativism and new methods that will make spaces for the outside and the outsider to the modern project. In many ways, the fields of Afrofuturism, the discourse on the Black Lives Matter movement, the continued radicalization of contemporary Christian nationalists, and the rise of populist leaders around the globe all beg for new forms and methods to shape our telling of history and visions for the future.

Joseph L. Tucker Edmonds is Assistant Professor of Africana Studies and Religious Studies at Indiana University-Purdue University Indianapolis.

\section{Religion as a Cultural System}

\section{Angie Heo}

First published in 1966, "Religion as a Cultural System" remains a sturdy classic in religious studies. In the opening of his essay, Clifford Geertz characterizes the anthropology of religion as a field that had plunged into a state of stagnation and self-provincialization since World War II. The damning diagnosis only foretold his ambition at the grandest tiers of theoretical innovation. Geertz's bold pitch for the uniqueness of religion was no less than a wager for essentialism that ended up serving as the raison d'être for the academic study of religion for decades, far beyond the purview of anthropology. If any figure gifted religious studies with its new lease on life, and at a moment in American history when Time magazine's cover asked, "Is God Dead?" (April 1966), Geertz is certainly a contending candidate. To the extent that we inquire after the nature and category of religion, Geertz's foundational concerns continue to reverberate widely in our writings and classrooms. 
Timeless as it has become, "Religion as a Cultural System" also emerged within a specific context definitive of Cold War America. It is the Americanness of Geertz's theory of religion that I broach here (and suitably, I think, in a journal whose very name pays homage to his influence on the study of American religion). In the aftermath of World War II, the United States began to envision a new imperial frontier in an era of freshly decolonized nation-states. The 1965 Immigration and Nationality Act, moreover, opened U.S. borders to future generations of American citizens with origins outside Europe, from Asia, Africa, and Latin America. The Cold War raged on in the 1960s and 1970s, advancing soul-searching anxieties over secularization and combating the global encroachment of atheist communism. Systems of equality, pluralism, and freedom were paramount to envisioning a changing America at home and abroad. Geertz's essay is, therefore, as much an historical document of its time, as it is an inaugural proposal for new directions of scholarly inquiry. Reflecting on its arguments about religion as culture allows us to probe where the American social sciences meet American history, and the extent to which Geertz's durable presence in our current curriculum is, in fact, distinctively American in nature.

\section{A Drag on Theory}

Geertz's commitment to religious pluralism shows in his tidy assemblage of the "Plain Indian's bravura, the Manus' compunctiousness, or the Javanese's quietism"-all equally representative portraits of the moods and motivations that are the substance of piety. More determined is his drive for an empirical explanation for what piety does in the world and how it affirms a worldview, or a common sense of "the really real." On multiple rereadings, I find myself struck by Geertz's expressed wonder toward sacred signs and what he argues to be their extraordinary capacity to calibrate lifestyle with lofty metaphysic, that is, to attune ordinary human experience with cosmic orders of existence, suffering, and the ultimate. Religion's unique domain of social action is, in all its generalizable potential, one that instructs and recommends a morally meaningful template of what is and what should be. More importantly, for Geertz, it is also a realm of diversity that flourishes with an authoritative pull on its adherents and with a significant measure of autonomy from the play of politics and the weight of history.

At least one of his teachers was not quite buying into his claim to scholarly advancement. Providing the commentary to Geertz's 
reprinted essay in The Religious Situation: 1968, Talcott Parsons airs in forthright fashion what bothers him most about it: "My question [is] how far Geertz is bound to a conception of 'cultural relativity' that is a drag on, rather than an asset, to the development of theory in social science." For Parsons, the development of theory in social science was probably the first thing on his mind. A Cold War enterprise sponsored by the Carnegie Corporation, Harvard's Department of Social Relations' charge was to formulate the general laws of social action, and via the institutional unification of sociology, anthropology, and psychology. From the vantage point of world modernization, the leveling work of culture was surely a drag on the American social sciences, and as Cold War America looked toward developing nations elsewhere. Yes, ethnocentrism was a relapse, but for Parsons, a minor one compared to the greater obstacle of relativism to universalist teleologies of freedom.

It is no secret that the internationalism of war often exerts pressure on anthropology to generate new theory, and for the American school of anthropology, new theories of culture. Franz Boas, the legendary founder of cultural relativism and of America's first department of anthropology at Columbia, was a Jewish German immigrant whose experience of the World Wars led to a concept of culture that was vitally antiracist, humanist, liberal, and cosmopolitan. During the early Cold War decades, Geertz would take up the Boasian mantle of relativism, but one that was shorn of the multiculturalist agendas for activism carried by public figures like Margaret Mead or Zora Neale Hurston. Geertz's main interlocutor was the towering academy of comparative science, and his ardent advocacy was for the place of the "cultural system" in Talcott Parsons's and Edward Shils's comprehensive theory of social action. In his commentary to Geertz's essay, Parsons's somewhat veiled dismissal of the surge in "sensitivity to the study of nonwestern cultures by western scholars" further underscored his evolutionist defense of the modern West as the bearer of "universal significance in the development of human society and culture."

As the following decades would soon tell, the tremendous success of Geertz's culture concept made a great deal of sense. In light of American liberal democratic expansion until the 1990s, Geertz was a spokesperson against evolutionist hierarchy and a champion for a world where a thousand flowers may bloom. An anthropologist who was at home in literature and philosophy, he also brokered a growing institutional divide between the sciences 
and the humanities during the Cold War. A social theorist of meaning, he toggled between value-free codes of communication on the one hand (e.g., the imprint learning of beavers and bees), and the deep play of textual interpretation on the other (e.g., the Problem of Evil). In the field of religious studies, mainline Protestantism discovered an eloquent ally in Geertz's grammar of translation, which described Navajo curing rites as "essentially a communion rite between the patient and the Holy People." Hence, theological pluralism gave way to new subdisciplines that took their bets on difference, with "culture" serving as the watchword for contextual, local, indigenous, and third-world theologies. Far from being a drag, relativism was the very propellant for a secular academy confronting newfound discomforts with Western triumphalism, and under the unapologetic shadows of Cold War science.

Numerous critics of the culture concept have since pointed out Geertz's disastrous blind spots. Forged in the crucible of the Cold War, Geertz's arguments for religion as culture were deafeningly silent on matters related to the bloody politics steps away from him. In 1965 and 1966, the Indonesian army purged well over half a million alleged communists in Java and Bali, including inside the very villages that set the scene for Geertz's reflections on the fear, cruelty, and Kierkegaardian leaps enacted in performances of Rangda and Barong. In 1971, Geertz served on a consulting mission in Jakarta for the Ford Foundation, an agency that had close connections to the American Central Intelligence Agency as well as the Indonesian military and cabinet. More than anyone else, he was well aware of American involvement in orchestrating Suharto's anticommunist massacres. Geertz's steely refusal to engage with the history and politics of his immediate context was disturbing, to say the least. One notorious footnote in his famous essay, "Notes on a Balinese Cockfight" (1973), bares the limits of culturalism: "It is merely to say that if one looks at Bali . . . also through the medium of its cockfights, the fact that the massacre occurred seems, if no less appalling, less like a contradiction to the laws of nature."

Geertz, an American scholar in 1960s Indonesia, chalked up the mass killings to the laws of nature and, to be more specific, to the semiotics of cultural system. With the benefit of hindsight, it turns out that relativism was indeed a drag on theory, but not for the reasons that Parsons expressed. The American academy's quest for a universal sciences of human behavior ended up replacing the vulgarity of evolutionism with coexisting, meaning-filled totalities that operate freely outside the ubiquitous violence of Cold War 
history. Geertz's concessions to the laws of nature, on behalf of the idiosyncrasies "unique" to religion, further gave license to the depoliticization of myth and ritual, as well as to the retreat of geographically specific traditions into islands of local knowledge. The ghettoization that marked area studies was all the more problematic as American influence grew to be so fiercely transnational and transregional throughout the Asian Pacific Rim, the Arab Middle East, Latin America, and around the world. Recognizing the Cold War origins of cultural pluralism also means asking how viable it is for the American academy in the present to imagine other countries-their founding myths, philosophical archives, ritual performances, archaeological heritages-as if they had ever marched on equally representative footing. Avoiding this question, it seems to me, would be nothing short of unscientific.

\section{The Empire Strikes Back}

The diminishing relevance of religious pluralism, as a model that explains our contemporary condition of religious difference, is not simply a scientific concern. This became crystal clear to me in an observation expressed by a senior officer at the Korea Foundation, a state-funded diplomacy organization with a mission to connect South Korea with other countries and, in its educational wing, to promote the study of Korean history and culture in foreign universities, including in the United States. Following an afternoon of research presentations, I commented on how impressed I was with the Korea Foundation's two fellows from Prague who were hard at work on Czech translations of Samguk Yusa, a thirteenth-century chronicle that transmits ancient founding folklore from the various Korean kingdoms. In his reply to me (a Korean-American scholar of Korean Christianity), the director-general wryly remarked that "Koreans are now more interested in the kingdoms of Judah and Israel than they are in their own."

Korean Protestantism, with its early twentieth-century origins in American mission history, is a diffuse and spectacular phenomenon. After World War II ushered in a new political age after colonialism, America's imperial reach further yielded mass waves of Christian conversion in early Cold War Korea. As history would have it, the empire strikes back. A country of only fifty million, South Korea currently boasts the largest megachurches on the global charts, and South Korean missionary zeal is legendary to the extent that Americans now figure as their targets of proselytization, as sociologist Rebecca Kim captures in The Spirit Moves West (2015). For 
cultural nationalists, the recent eclipse of Buddhist wisdom and founding myths of Dangun and King Dongmyeong by old Anglican hymns and Hebrew and Greek language classes prompts legitimate anxiety around disappearing signs of heritage and ethnic distinction. In such circumstances, neither Geertzian frames of cultural relativism nor Parsonian apologies for social evolutionism offer much explanatory appeal. Few seem to care for Korean native religion, and nobody aspires to be "America's second" in any field.

To be sure, South Korea is not alone in its political bind between cultural nativism and universal development. Five decades running after 1968, scholars of religion must now address a greater global condition found in countries like Brazil, Russia, Nigeria, the Philippines, and China, where Christianity's explosive growth during the Cold War serves to index those particular forms of religion that complemented the dawn of late capitalism, to the overwhelming exclusion of other traditions and experiences. In our "Religious Situation: 2018," the redemptive potential of multiculturalist pluralism (e.g., brown Jesus in dialogue with white Jesus) doesn't quite seem to pass the muster of historical and geopolitical realities. And so, we're back to the drawing board in pursuit of theoretical innovation, but this time, perhaps in a better position with a couple of key pointers learned from the last round.

The first is to reengage the critical relationship between religion and political economy, even at the risk of surrendering religion's uniqueness. Here, I purposely say "reengage" to signal Max Weber's originary core concern with what religion does and how it transforms in conjunction with specific features of modern capitalism. As Protestant Christianity's many-sided aspects in South Korea and other countries attest, religious growth does not merely parallel processes of Cold War development and postCold War globalization; it is deeply intertwined with them. Instead of containing religion into a coherent system of special signs, the proposal is to tackle the unwieldy and distributive contents of religion head-on, along with its uneven synchrony with financial speculation, humanitarian aid, labor migration, and the global swell of middle-class consumption. This also means setting aside consciousness-oriented perspectives on religionGeertz's moods and motivations as well as Marx's ideology, a similarity that Talal Asad noted in his well-known critique, "The Construction of Religion as an Anthropological Category" (1993). One of the liabilities associated with the Cold War's influence on religious studies, of which the liberal politics of culturalism was a 
major part, is an underlying anti-Marxist prejudice that eschews historical materialist approaches. Inquiring after religion's shape-shifting forms in observable relation to the undeniably real forces of capitalism may help mitigate against one of our field's stubborn blind spots.

This brings me to the second task at hand, one driven by the global presence of America, American religion, and American empire, especially during and after the Cold War. Since the 1990s at least, the transnational turn in American studies writ large has ignited interest in the diasporic and international ambit of American literature, architecture, law, activist movements, and the list goes on. American mission history, a longstanding subfield in church history, has certainly addressed the influence of Presbyterian and Methodist missionaries abroad, with more than an insightful few of its Korean experts lamenting to me that it was the conservative Christians who ended up crossing the Pacific. Indeed, it is impossible to overlook the particular brand of "Americanness" that inspired Korea's megabrand of Evangelicalism, from the purpose-driven likes of Rick Warren on Seoul's subway ads to the Islamophobic propaganda against Yemeni refugees seeking asylum on Jeju Island. What is most needed is a more critical engagement with mission history, in the ways that the life of religion not only broke ground in education and medicine, but also brokered an entirely political-economic vision of the "Free World," many times hand in hand with anticommunist military campaigns. The Geertzian quest for cultural pluralism, against the sobering asymmetries of scale and power, pales in sheer comparison to Cold War histories of American empire and Third World nation-building. We can no longer afford to understand America solely through the bounded acts of American individuals and American institutions. We also need to engage with America's very material legacies from the perspective of non-Americans in the present. Even now, in 2018, I suspect that some variation of the Korea Foundation director's subtle retaliation against displaced origins may be found in any other postcolonial nation reckoning with the historical fallouts from Cold War empire. That is also part of our history.

Angie Heo is Assistant Professor of Anthropology and Sociology of Religion at The University of Chicago Divinity School. The Korea Foundation's Fellowship for Field Research in 2018 supported her work for this publication. 


\section{Ritual}

\section{Ari Y. Kelman}

\section{The Ritual in Retrospect}

In the original volume, the selection of essays about ritual cluster around two interrelated themes: evolution and survival. The presence of these themes in essays about ritual can be understood as a kind of thematic carryover from the forum in which these essays originally appeared: a 1966 issue of The Philosophical Transactions of the Royal Society of London (the world's first and longest-running scientific journal). In the broader context of 1968, however, these thematic preoccupations suggest something other than a strictly scientific interest. In the context of religion, they suggest larger concerns about the nature of change at a moment when so much of what seemed predictable, comprehensible, regular, and ritualized about the operations of everyday life began to seem, somewhat suddenly, less so.

Julian Huxley, who organized the initial symposium and whose essay appears first in the section, closes his comments with an observation that frames the crises of the day in ritual terms. He points to "the weakening of traditional religious systems" and the fact that "the United National and its supra-national activities have been very poorly ritualized" as evidence that at least some of the global tumult can be traced to "the failure of existing human groups . . . to ritualize their behavior adequately or effectively in relation to the radically new psychosocial situations of today" (708). The weakened status of ritual, for Huxley, suggests something worse than just a loss of ceremony.

Borrowing from his disciplinary training as an evolutionary biologist, Huxley concerned himself with canalization, a term used to describe the process by which generically similar populations reproduce the same phenotype, regardless of genotypic diversity. In sociocultural terms, it is the measure of a population's ability to maintain a kind of cultural stability as evidenced by its ability to reproduce itself from generation to generation. The loss of ritualized behavior, Huxley feared, brought canalization into question.

Huxley was not alone in his concern. The other authors in the section on ritual, including Erik Erikson, Konrad Lorenz, Edward Shils, William F. Lynch, and Nikita Struve (who wrote about "pseudo-religious rites in the USSR") all organized their contributions around a similar concern with the weakened status of 
ritual, its function and meaning. Although they did not all focus on its explicitly "religious" dimensions, they nevertheless found common ground in their insights into the relationship between the status of ritual during a time when questions of change and survival were very much in the air

Together, they seem to be asking some version of the following: If ritual, at its core, is about repetition, and repetition is, essentially, about reproduction (or at least maintenance), then what happens when the mechanisms of social and cultural reproduction begin to weaken? Does a decrease in the performance of rituals indicate a decrease in social cohesion, generally? Conversely, what happens when new social forms emerge but without the ritual frameworks of older ones? Is it possible to imagine a social order or any of the institutions dedicated to its maintenance, perpetuation, and transmission, without rituals of one sort or another?

This is not a trivial matter if we understand that rituals are, essentially educational. They require a modicum of understanding about one's relationship to a particular tradition, and they reinforce, by repetition and by enculturation, an orientation to certain concepts, practices, and dispositions within that tradition. We can think here, most obviously, about prayer or about life-cycle events, and we can also think about tithing, naming ceremonies, graduations, or of singing the "Star Spangled Banner" before a sporting event. Each of these examples channels attention and knowledge toward the ritual practice itself (embodied, sonic, sensorial, etc.) and toward the larger context in which singing, eating, or facing Mecca might be understood as meaningful in the first place.

Understood as educational, rituals play a crucial role in the transmission of cultural norms and expectations. They make habits out of habitus and they make habitus out of habits. Through ritual, people learn how to be Catholics or Muslims, Jews or football fans (to say nothing of the various combinations of those categories). And they learn by practicing rituals. Of course, people learn things that the rituals were likely not meant to teach-like the boredom of rote recitation or the terror associated with doing things "wrong." But the crux of ritual, at least for Huxley and Erickson and the others who contributed to this volume, was how ritual might facilitate a kind of social or cultural stability amid the pressures of evolutionary or political change. In that view, neither rote repetition nor ritual's complete erasure seemed like desirable outcomes.

As Erickson concluded, ritual is all about the creation and maintenance of the social order through regular and regulated interactions. Ritual, he wrote, "is an unexpected renewal of a 
recognizable order in potential chaos. Ritual thus depends on that blending of surprise and recognition which is the soul of creativity, reborn out of the abyss of instinctual disorder, confusion of identity, and social anomie" (732). He argues that regulation and ritualization stabilized all of these forces. Ritual for ritual's sake, he believes, is the worst kind of ritual because it does not allow for active transmission of the forms or the ideas that animate it in the first place. But without ritual, disorder, confusion, and anomie will reign.

Crisis, about which Erickson knew a thing or two, can give way to order through the transformative magic of ritual. Yet, as Huxley and Erickson explain, it seems that ritual forms may have succeeded too well, providing too much order, too much predictability, too much social coercion, too much identity stability. And in the mid-1960s, just as Erickson was thinking through the challenges of identity and Huxley was reflecting on canalization, the ritual forms were beginning to crack.

Sacred rituals-and we can take a definition of "sacred" here that is broad enough to include examples of civil religion, toobegan to lose their ability to enchant people into perpetuating them. Whether it was the ritual that broke down or the underlying values that stopped compelling people to participate is a chicken-egg kind of question, but it is safe to conclude that both Huxley and Erickson understood that ritual, repetitive though it may remain, is not what it used to be.

\section{Ritualizing the Future}

So, what has ritual become, some fifty years hence? In some respects, Erickson's and Huxley's fears have not been realized. The social orders of the midcentury have not entirely broken down (for better and for worse), religion has not disappeared (for better and for worse), and rituals of all kinds remain as strong and popular as ever. Oddly, and what neither Huxley nor Erickson could have predicted is the persistent desire for ritual without concern for its specifically reproductive functions, and beyond the bounds of cultural communities.

One of the best examples (there are many) is the arrival of the "Ritual Design Lab," a perfectly Silicon Valley invention committed to harnessing "the power of rituals to build value, meaning and community into our everyday experiences," as their website boasts. Rituals, they explain, "are actions performed by people that bring higher-and perhaps illogical, magical, and delightful-meaning into their experiences." For the RDL, rituals are largely about 
meaning and, specifically, about invoking a "higher" meaning, however that might look, sound, or feel.

The emergence of the Ritual Design Lab, and the appearance of rituals for divorce, for Mondays, for entering new work communities, for moving to a new house, for getting a driver's license, for going to college, or for interacting with nonhuman actors (e.g., ATMs, autonomous vehicles), suggest that people want and need rituals for precisely the reasons that Erickson and Huxley suggest. People wish to understand how they are moving through their lives, and they fail to find opportunities to do so with the repertoires of many established religious communities. So, they're making them up on their own.

This approach fundamentally changes the definition of ritual. Unlike the conception of ritual as a prescribed, disciplinary form meant to foster continuity through repetition, the RDL and other ritualists, both secular and religious, trade in the provision of making meaning out of marking events. Repetition, reproduction, and canalization are all out. Symbols, personal meaning, and customization are in. Anyone, anywhere can declare any action to be a "ritual." It needs no theology, save that of the ritual itself, no community, no tradition, no history, no other adherents, and no logic beyond that offered by the ritualists themselves. It is radically open and radically unmoored.

What is missing from this vision is precisely the sense of ritual that captivated Erickson and Huxley and the other contributors to the original volume: Rituals have histories or are tethered to specific communities that bear certain repertoires of knowledge or common dispositions about how the universe is ordered. Gone, too, from this definition is a sense that repetition is part of what makes rituals so powerful. To avoided the dreaded "rote ritual" label, once is plenty.

Erickson and Huxley would agree here that rituals are occasions for making meaning and reflection, but they would depart from the emerging notion that rituals are largely about the experience of the individual participant. For Huxley and Erickson, meaning is not personal but cultural; its power comes from the fact that it is shared with others both synchronically and diachronically. A one-time ritual, they would conclude, is hardly a ritual at all.

In his concluding remarks to the conference whose proceedings were published in Philosophical Transactions, Erikson observed that the question is not whether ritual will allow humans to survive in the future, but whether, without ritual, they would have survived this long. The emergence of the RDL and the surfacing of 
so many ritualized responses to life in the twenty-first century answer Erikson's question in both the affirmative and the negative.

People seem to want ritual for themselves, but not necessarily for its power to reproduce communities, cultures, or connections. There seems to be a desire for ritual, bespoke and neoliberal, customized and tailored, ephemeral and decontextualized although it might be. And one does not have to look too far to see crisis and anomie lurking on the horizon. Ritual does promise to salve those sentiments at precisely the moments in life where they seem most threatening and the orders on which we rely (often without acknowledging them) seem so precarious.

The RDL is not the point here; it is just a symptom of the larger changes afoot in religious worlds in a secular age, in which the ritual form has, perhaps, succeeded too well. The desire to keep precariousness at bay, to remind ourselves why we are doing what we are doing, and to reaffirm our commitments seem, all things considered, to be reasonable responses. Modern and enlightened though we are, simply acknowledging crisis and anomie does not satisfy those experiencing it. The addition of a ritual-a symbolic layer-atop the realities of life seems, for many, a better way to understand just what is going on.

The power of the ritual at the end of the enlightenment, then, might be found in the ritual form, itself. Organized religions certainly continue to offer ritual moments and frameworks, and many people still innovate within those frameworks. Yet, ritual remains powerful even for those who opt out or opt elsewhere, religiously. This would disappoint Erikson and Huxley, because one-off rituals cannot do the reproductive work they so value. Yet, the popularity of bespoke rituals suggest that it remains a powerful cultural form, more powerful in some respects, than the specific religious contexts from which they emerged. What is lost in neoliberalism might be found in rituals that acknowledge that the world is challenging and ever-changing, that it remains full of mystery, and that ritual might allow us humans to recall a bit of that mystery amid the pressures of late modernity.

Ari Y Kelman is the Jim Joseph Professor of Education and Jewish Studies at the Stanford Graduate School of Education. 